\title{
Flora fanerogâmica da Serra do Ouro Branco, Minas Gerais: Myrtaceae
}

\author{
Flora of the Serra do Ouro Branco, Minas Gerais: Myrtaceae
}

\author{
Matheus Fortes Santos ${ }^{1,4}$ \& Paulo Takeo Sano ${ }^{1}$
}

\begin{abstract}
Resumo
Myrtaceae é uma das famílias mais representativas da flora brasileira, fato que não tem sido acompanhado por um número expressivo de trabalhos taxonômicos. O presente estudo teve como objetivo realizar o tratamento taxonômico para a família na Serra do Ouro Branco, o ponto mais ao sul da Serra do Espinhaço. Foram registrados 10 gêneros e 24 espécies para a região: Accara $(1 \mathrm{sp}$.$) , Blepharocalyx (1 \mathrm{sp}$.$) , Calyptranthes (2$ spp.), Campomanesia (2 spp.), Eugenia (2 spp.), Marlierea (2 spp.), Myrceugenia (2 spp.), Myrcia (10 spp.), Psidium (1 sp.), Siphoneugena (1 sp.). São apresentados chaves de identificação, descrições e comentários sobre gêneros e espécies.
\end{abstract}

Palavras-chave: campo rupestre, Eugenia, Myrcia, Serra do Espinhaço, taxonomia.

\begin{abstract}
Myrtaceae is one of the most representative families of the brazilian flora, but this have not led to an expressive number of taxonomic treatments. The aim of this study was the taxonomic treatment of the family in the Serra do Ouro Branco, the southernmost point of the Espinhaço Range. Ten genera and 24 species have been recorded from the area: Accara (1 sp.), Blepharocalyx (1 sp.), Calyptranthes (2 spp.), Campomanesia (2 spp.), Eugenia (2 spp.), Marlierea (2 spp.), Myrceugenia (2 spp.), Myrcia (10 spp.), Psidium (1 sp.), Siphoneugena (1 sp.). Identification keys, descriptions and comments of genera and species are presented.

Key words: campo rupestre, Eugenia, Myrcia, Espinhaço Range, taxonomy.
\end{abstract}

\section{Introdução}

Myrtaceae engloba 3.800-5.600 espécies divididas entre cerca de 140 gêneros (Wilson et al. 2001; Govaerts et al. 2006), com centros de diversidade na Austrália, no sudeste da Ásia e na América tropical e subtropical (porção sul) (Wilson et al. 2001). Está incluída na ordem Myrtales (APG 2009), sendo caracterizada pela combinação das seguintes características: folhas inteiras com glândulas de óleo essencial, ovário semi-ínfero ou ínfero, estames geralmente numerosos, floema interno e pontuações guarnecidas nos vasos xilemáticos (Wilson et al. 2001). Tradicionalmente, Myrtaceae era dividida em dois grandes grupos: Myrtoideae, com fruto bacoide, e Leptospermoideae, com fruto capsular. Diversos trabalhos têm mostrado que estes grupos não são monofiléticos e que esta divisão deve ser abandonada (Johnson \& Briggs 1984; Wilson et al. 2001, 2005). A classificação mais atual para a família foi proposta por Wilson et al. (2005), dividindo-a em duas subfamílias,
Psiloxyloideae e Myrtoideae, contendo duas e 15 tribos, respectivamente.

Dentre as 15 tribos de Myrtoideae figura Myrteae, que engloba todas as espécies neotropicais da família, exceção feita ao gênero Tepualia Griseb. (McVaugh 1968; Landrum \& Kawasaki 1997; Lucas et al. 2005). Myrteae conta com 49 gêneros e cerca de 2500 espécies (Govaerts et al. 2006) e apresenta distribuição pantropical, com maior diversidade na América do Sul e no Caribe (McVaugh 1968). Distingue-se das outras tribos de Myrtoideae (sensu Wilson et al. 2005) por apresentar fruto bacoide indeiscente, sistema vascular transeptal e, comumente, presença de tricomas uni e multicelulares (Schmid 1972; Wilson et al. 2001). A classificação mais amplamente utilizada de Myrteae foi feita por Berg (1855-56, 1857-59), baseada nos três tipos básicos de embrião encontrados no grupo, porém, estudos efetuados por Lucas et al. $(2005,2007)$, baseados em dados moleculares combinados, mostraram que tais

\footnotetext{
${ }^{1}$ Universidade de São Paulo, Instituto de Biociências, Depto. Botânica, Lab. Sistemática Vegetal, R. do Matão 277, 05508-090, São Paulo, SP, Brasil.

${ }^{4}$ Autor para correspondência: matheus_fs@yahoo.com.br
} 
classificações não refletem grupos monofiléticos. Lucas et al. (2007) propuseram sete grupos dentro de Myrteae, mas não foram estabelecidas categorias supragenéricas formais.

As Myrtaceae neotropicais apresentam grande complexidade taxonômica, o que resulta em enorme dificuldade no reconhecimento de gêneros e espécies, fato exacerbado pelo uso de caracteres crípticos na diagnose de gêneros, pelos limites intergenéricos pouco compreendidos (McVaugh 1968; Landrum \& Kawasaki 1997) e pelo baixo número de estudos sobre a família (Nic Lughadha \& Snow 2000). Estudos filogenéticos, essenciais para uma classificação robusta do grupo, têm avançado apenas nos últimos anos (Lucas et al. 2005, 2007; Mazine 2006; Lucas et al. 2011).

No Brasil, Myrtaceae conta com 24 gêneros e cerca de 1.000 espécies (Landrum \& Kawasaki 1997; Sobral et al. 2012). É notória a grande representatividade da família na flora brasileira, com destaque para a Mata Atlântica, domínio vegetacional onde se apresenta invariavelmente entre as famílias de mais alta riqueza (OliveiraFilho \& Fontes 2000). Na Serra do Espinhaço, formação geológica onde se situa a área de estudo, também figura entre as famílias com maior número de espécies (Giulietti et al. 1987; Pirani et al. 2003; Zappi et al. 2003). Ao contrário do panorama geral, alguns trabalhos taxonômicos vêm sendo realizados na Serra do Espinhaço, fornecendo valiosos dados para a sistemática da família (Kawasaki 1989, 2004; Nic Lughadha 1995).

O extremo sul do Espinhaço, onde se situa a Serra do Ouro Branco, ainda não havia sido alvo de coletas e estudos específicos. O presente estudo realizou o tratamento taxonômico das espécies de Myrtaceae da Serra do Ouro Branco, apresentando descrições, ilustrações, chaves de identificação e comentários sobre os gêneros e as espécies.

\section{Material e Métodos}

\section{Área de estudo}

A Serra do Ouro Branco $\left(20^{\circ} 28-30^{\prime} \mathrm{S}\right.$, $\left.43^{\circ} 41^{\prime} \mathrm{W}\right)$ representa o extremo sul da Serra do Espinhaço, apresentando-se disjunta da porção conhecida como Espinhaço Meridional, situando-se próxima ao conjunto de elevações do Quadrilátero Ferrífero (Almeida-Abreu 1995) (Fig. 1). Assim como o Espinhaço Meridional, é formada, sobretudo, pelas rochas predominantemente quartzíticas do Supergrupo Espinhaço (Almeida-Abreu 1995; Almeida-Abreu \& Ranger 2002). Apresenta-se como uma elevação abrupta, formando, a sudeste, um paredão com aproximadamente $17 \mathrm{~km}$ de extensão e, a nordeste, declividades que delimitam vales a partir de um planalto de altitudes entre 1.250 e $1.608 \mathrm{~m}$. Está inserida inteiramente no município de Ouro Branco (MG), com área de aproximadamente 2.750 ha. A região apresenta chuvas entre novembro e fevereiro e estação seca no inverno; a temperatura média é de $20,7^{\circ} \mathrm{C}$ e a precipitação anual é de 1.188,2 mm.

\section{Metodologia}

Expedições de coleta foram efetuadas na Serra do Ouro Branco entre 2002 e 2006 pelo Departamento de Biologia Vegetal da Universidade Federal de Viçosa, com as amostras depositadas no herbário VIC (acrônimos de herbários segundo Thiers em contínua atualização). Além destes materiais, foram também utilizadas, neste trabalho, exsicatas depositadas nos herbários BHCB e SPF. Materiais adicionais foram utilizados quando havia apenas espécimes inférteis coletados na Serra, sendo incluídas na descrição somente as estruturas reprodutivas.

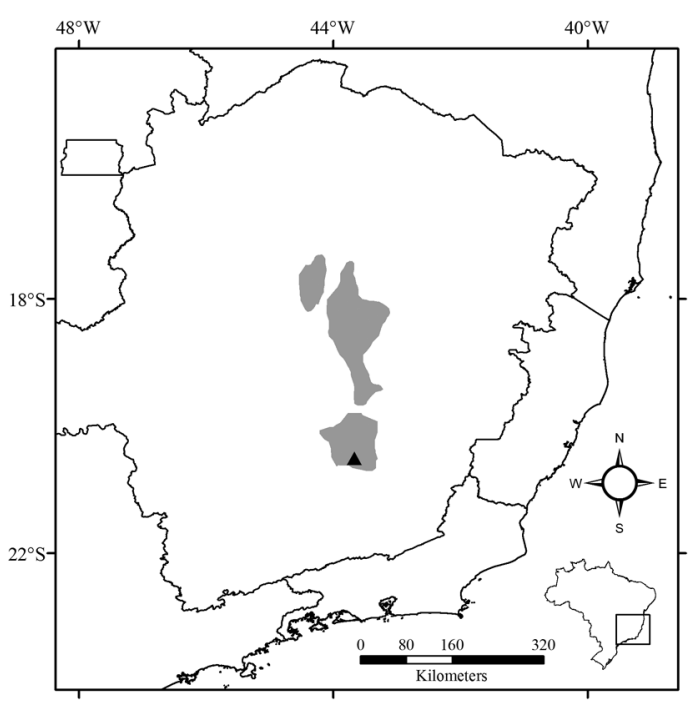

Figura 1 - Localização da Serra do Ouro Branco (triângulo preto) no estado de Minas Gerais. Em cinza, é mostrada a extensão aproximada da Serra do Espinhaço Meridional (partes norte e oeste) e do Quadrilátero Ferrífero (parte sul). A linha contínua delimita os estados brasileiros.

Figure 1 - Localization of the Serra do Ouro Branco (black triangle) in the Minas Gerais state. Gray area delineates the Meridional Espinhaço Range (northern and western parts) and the Quadrilátero Ferrífero (southern part). The continuous line delineates the Brazilian states. 
A terminologia morfológica adotada baseou-se em Radford et al. (1974) e em trabalhos taxonômicos específicos para a família (Berg 1857-59; McVaugh 1968; Landrum \& Kawasaki 1997). A descrição dos gêneros também foi baseada nestes autores, sendo incluídas apenas características das espécies presentes na área de estudo.

\section{Resultados e Discussão}

Na Serra do Ouro Branco foram encontrados 10 gêneros e 24 espécies de Myrtaceae: Accara Landrum (1 sp.), Blepharocalyx O. Berg (1 sp.), Calyptranthes Sw. (2 spp.), Campomanesia Ruiz \& Pav. (2 spp.), Eugenia L. (2 spp.), Marlierea Cambess. (2 spp.), Myrceugenia O. Berg (2 spp.), Myrcia DC. ex Guill. (10 spp.), Psidium L. (1 sp.), Siphoneugena O. Berg (1 sp.). A Tabela 1 mostra o número de gêneros e de espécies de Myrtaceae deste e de outros estudos realizados em áreas de campo rupestre na Serra do Espinhaço.

$\mathrm{O}$ número de gêneros é semelhante entre as áreas, sendo que tal fato provavelmente decorre da ampla distribuição geográfica dos gêneros de Myrtaceae ocorrentes no Brasil (Landrum \& Kawasaki 1997). Ainda que se possa perceber que alguns gêneros são mais diversificados em alguma região ou fitofisionomia, e.g., Myrceugenia na Floresta Ombrófila Mista (Landrum 1981), esses comumente apresentam uma ou mais espécies de ampla distribuição. Com relação ao número de espécies, nota-se que a Serra do Ouro Branco tem menor riqueza, o que provavelmente é reflexo de sua pequena área (ca. $27 \mathrm{~km}^{2}$ ) em relação às áreas abordadas nos outros estudos (mais de 200 $\mathrm{km}^{2}$ ). Consequentemente há baixa diversidade de fitofisionomias, o que limita a ocorrência de espécies exclusivas de certos ambientes. Além disso, a Serra do Ouro Branco é alvo de perturbação antrópica em toda sua extensão, o que também pode contribuir para a diminuição da diversidade florística.

A maior parte das espécies encontradas na Serra do Ouro Branco apresentam ampla distribuição em áreas florestais e no cerrado, destacando-se:
Tabela 1 - Número de gêneros e espécies de Myrtaceae em estudos florísticos realizados em campo rupestre na Serra do Espinhaço.

Table 1 - Number of genera and species of Myrtaceae in floristic studies carried out in campo rupestre in the Espinhaço Range.

\begin{tabular}{lcc}
\hline & Gêneros & Espécies \\
\hline $\begin{array}{l}\text { Serra do Ouro Branco } \\
\text { (presente estudo) }\end{array}$ & 9 & 22 \\
$\begin{array}{l}\text { Serra do Cipó } \\
\text { (Kawasaki 1989) }\end{array}$ & 10 & 46 \\
$\begin{array}{l}\text { Pico das Almas } \\
\text { (Lughadha 1995) }\end{array}$ & 9 & 30 \\
$\begin{array}{l}\text { Serra do Catolés } \\
\text { (Zappi et al. 2003) }\end{array}$ & 10 & 53 \\
$\begin{array}{l}\text { Grão-Mogol } \\
\text { (Kawasaki 2004) }\end{array}$ & 9 & 34 \\
$\begin{array}{l}\text { Serra do Caraça } \\
\text { (Morais \& Lombardi 2006) }\end{array}$ & 12 & 52 \\
\hline
\end{tabular}

Blepharocalyx salicifolius O. Berg, Calyptranthes clusiifolia O. Berg, Campomanesia adamantium (Cambess.) O. Berg, Eugenia bimarginata DC., Myrcengenia alpigena (DC.) Landrum, Myrcia amazonica DC., Myrcia splendens (Sw.) DC. e Myrcia tomentosa (Aubl.) DC. (Sobral et al. 2012). Nos outros estudos realizados na Serra do Espinhaço, nota-se a recorrência de tal padrão, havendo apenas casos pontuais de micro-endemismo (e.g., Landrum 1990; Kawasaki 2004; Proença et al. 2006).

No caso desse estudo, pode-se destacar a ocorrência de Accara elegans (DC.) Landrum, gênero monotípico endêmico dos campos rupestres do Quadrilátero Ferrífero e da porção sul da Serra do Espinhaço (Landrum 1990). Inclusive, A. elegans consta como "Vulnerável" na lista de espécies ameaçadas da flora de Minas Gerais (Biodiversitas 2007). Como destacado acima, a Serra do Ouro Branco tem sido alvo de intensa perturbação antrópica (criação de gado, fogo, etc.), porém, a recente criação do Parque Estadual da Serra do Ouro Branco (em setembro de 2009) deve contribuir para a preservação das populações das espécies registradas nesta flora e da Serra como um todo.

\section{Chave de identificação para gêneros de Myrtaceae da Serra do Ouro Branco}

1 Inflorescência em panículas.

2. Cálice fechado no botão floral, antese por caliptra 3. Calyptranthes

2'. Cálice aberto ou parcialmente fechado no botão floral.

3. Cálice em geral parcialmente fechado no botão floral; lobos do cálice geralmente rompendose irregularmente na antese 6. Marlierea

3'. Cálice aberto no botão floral; lobos do cálice regulares 8. Myrcia 
1'. Inflorescência de outro tipo.

4. Flores 4-meras; ovário 2-4-locular.

5. Hipanto circunciso na altura do ovário

10. Siphoneugena

5'. Hipanto não circunciso na altura do ovário.

6. Cálice fechado no botão floral (ou apenas o ápice aberto), antese em 4 lobos regulares 1. Accara

6'. Cálice aberto no botão floral.

7. Bractéolas decíduas; lobos do cálice decíduos

2. Blepharocalyx

7’. Bractéolas persistentes; lobos do cálice persistentes.

8. Pedicelos florais às vezes superpostos nas axilas foliares; ovário 2-4-locular; embrião com radícula alongada e cotilédones foliáceos e dobrados (embrião mircioide) 7. Myrcengenia

8'. Pedicelos florais nunca superpostos; ovário 2(3)-locular; embrião com radícula inconspícua e cotilédones carnosos (embrião eugenioide)

5. Eugenia

4'. Flores (4)5-meras; ovário 3-18- locular.

9. Nervura marginal ausente; ovário com lóculo glandular formando uma pseudotesta na semente; semente sem testa óssea 4. Campomanesia

9'. Nervura marginal presente; ovário sem lóculo glandular; semente com testa óssea

9. Psidium

\section{Accara Landrum}

1.1. Accara elegans (DC.) Landrum, Syst. Bot. 15: 221. 1990.

Fig. 2a

Subarbusto a arbusto $0,5-2 \mathrm{~m}$ alt., ramificação monopodial, ramos glabros. Lâmina 1,5-4,2 × 0,5-1,9 cm, subcoriácea, estreitamente elíptica a elíptica ou oblanceolada, ápice agudo, base aguda a estreitamente aguda, margem revoluta, glabra; face adaxial com pontuações impressas, nervura central impressa a sulcada, nervuras laterais inconspícuas, nervura marginal levemente sulcada no material seco; face abaxial com pontuações numerosas e salientes ou impressas, nervura central saliente, nervuras laterais inconspícuas; pecíolo 1-2 mm compr., canaliculado, glabro. Inflorescência 1-flora, axilar. Pedicelo $0,7-2 \mathrm{~cm}$ compr., rubro, glabro. Bractéolas ca. $3,7 \mathrm{~mm}$ compr., decíduas, estreitamente triangulares, côncavas, ápice acuminado, base truncada, tricomas esparsos. Botão floral 4,5-6,9 mm compr., verde-avermelhado, globoso. Flor 4-mera; hipanto róseo, glabro, pontuações presentes ou não, ápice não-prolongado sobre o ovário; cálice fechado no botão floral ou aberto no ápice, lobos 1,8-4,4 mm compr., regulares, ovado-triangulares, ápice obtuso, base às vezes fusionada após a antese, externamente verdes a róseos, glabros, verrucoso-glandulares, internamente com pilosidade alva; pétalas ca. $4 \mathrm{~mm}$ compr., alvas, obovadas, externamente pilosas, internamente glabras; estames creme, filetes glabros, anteras oblongas; ovário 4-locular, lóculo ca. 5-ovulado, estilete róseo, cilíndrico, estigma róseo, capitado. Fruto maduro vináceo a negro, globoso, glabro, verrucoso-glandular; lobos do cálice persistentes, patentes, côncavos; semente mais de 10 por fruto, aproximadamente reniforme, testa crustácea; embrião mirtoide.

Material examinado: 2.X.1988, f1., E.D.G. Campos (BHCB 14044); 28.V.1997, fl. e fr., M.L. Kawasaki et al. 1009 (SPF); 21.IX.2002, fl., C.C. Paula et al. 308 (SPF, VIC); 7.XII.2002, fr., C.C. Paula et al. 506 (SPF, VIC); 21.XII.2002, fl., C.C. Paula et al. 546 (SPF, VIC); 8.I.2006, fr., M.F. Santos et al. 53 (BHCB, SPF, VIC); 9.I.2006, fr., M.F. Santos et al. 88 (K, SPF, VIC).

Accara é monoespecífico e foi proposto para posicionar esta espécie, que já fora incluída em Myrtus L., do qual difere pelo número de peças do verticilo e pela estrutura do cálice, e Psidium L., do qual difere pelo número de peças do verticilo e estrutura da semente e do embrião (Landrum 1990). Caracteriza-se principalmente por apresentar cálice fundido no botão e lobos regulares na antese; no campo, destaca-se pelas folhas inclinadas em relação ao ramo e pelo porte subarbustivo. Foi coletada na Serra do Ouro Branco com flor de setembro a dezembro e com frutos de dezembro a janeiro. Na região, é encontrada em afloramentos rochosos e em campos graminoides. Ocorre em campos rupestres no Quadrilátero Ferrífero e na porção sul da Serra do Espinhaço (Landrum 1990). 

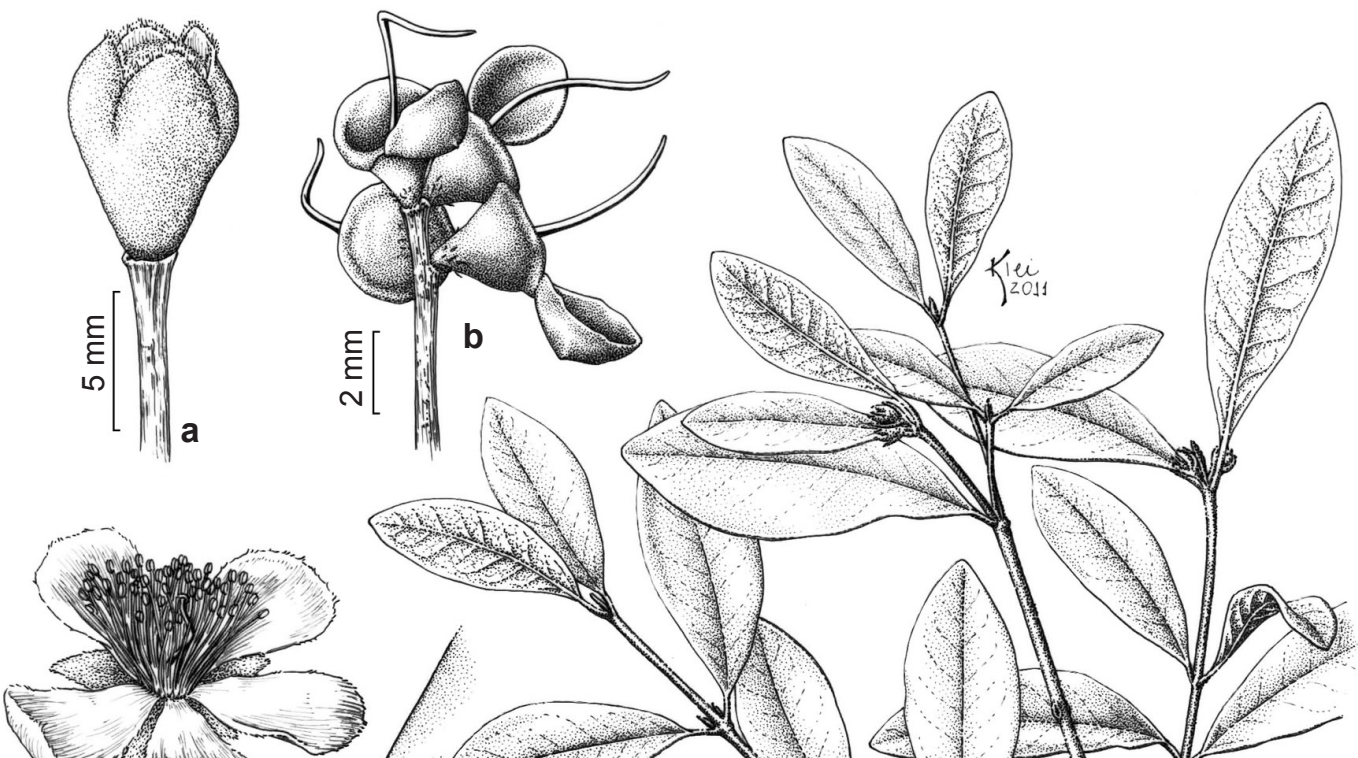
2. Blepharocalyx O. Berg

2.1. Blepharocalyx salicifolius (Kunth) O.Berg, Linnaea 27: 413. 1856.

Arbusto a árvore, altura desconhecida, ramificação monopodial, ramos imaturos vilósulos, ramos maduros glabrescentes. Lâmina foliar 2,3-2,9 $\times 1-1,6 \mathrm{~cm}$, subcoriácea, elíptica, ápice arredondado, base cuneada, margem revoluta; face adaxial glabrescente a glabra, pontuações impressas, nervação impressa a saliente; face abaxial com tricomas esparsos, principalmente na nervura central, pontuações salientes, nervação saliente; pecíolo $3-5 \mathrm{~mm}$ compr., canaliculado, piloso a glabrescente. Inflorescência 1-flora, axilar. Pedicelo 7-10 mm compr., vilósulo. Bractéolas ca. 2,5 mm compr., decíduas, lineares, ápice acuminado, base truncada, vilósulas. Botão floral ca. 3,5 mm compr., globoso. Flor 4-mera; hipanto vilósulo externamente, ápice não-prolongado sobre o ovário; cálice aberto no botão floral, lobos 18-24 mm compr., decíduos após a antese, suborbiculares, côncavos, ápice arredondado, externamente pubescentes, pontuações salientes, margem ciliada, internamente vilósulos; pétalas ca. 2,4 mm compr., suborbiculares, externamente com tricomas esparsos, margem ciliada, internamente pubérula, pontuações salientes; estames de filetes glabros, anteras oblongas; ovário 2-locular, estilete cilíndrico, glabro, estigma punctiforme. Fruto não visto.

Material examinado: 2.X.1988, fl., K. Marques (BHCB 13910); 2.X.1988, fl., T.M.F. Motta (BHCB 13987).
Blepharocalyx salicifolius se distingue das outras espécies de Myrtaceae da Serra do Ouro Branco pela combinação de inflorescência 1-flora ou dicasial (não visto no material analisado), pelo cálice aberto no botão floral e com lobos decíduos na antese. Apresenta ampla variabilidade morfológica quanto à pubescência e forma da lâmina foliar, fato que levou à proposta de numerosos binômios. Landrum (1986) sinonimizou-os com base no padrão contínuo destas variações e na uniformidade da estrutura da inflorescência, flor e fruto. Na Serra do Ouro Branco, foi coletada em floração no mês de outubro, em campo rupestre. Ocorre de Goiás ao Rio Grande do Sul, além de Paraguai, Uruguai, norte da Argentina, Bolívia e Equador, principalmente em áreas florestadas (Landrum 1986).

\section{Calyptranthes Sw.}

Árvores, arvoretas ou arbustos; ramificação simpodial. Inflorescência geralmente um par de panículas. Bractéolas decíduas. Cálice fechado no botão floral, antese por caliptra; pétalas $0-5$; ovário 2-locular, lóculo 2-ovulado, estigma punctiforme. Fruto coroado por uma cicatriz circular; semente 1-2 por fruto; embrião com radícula alongada e cotilédones desenvolvidos, foliáceos e dobrados (embrião mircioide).

Gênero de distribuição neotropical, do México e Caribe até o norte da Argentina. Possui cerca de 300 espécies (Govaerts et al. 2006).

\section{Chave para identificação das espécies de Calyptranthes da Serra do Ouro Branco}

1. Lâmina foliar 21-27,5 × 5,4-9 cm, oblonga .

3.1. C. clusiifolia

1'. Lâmina foliar 1,6-2,5 × 1-1,5 cm, obovada 3.2. C. pulchella

3.1. Calyptranthes clusiifolia O.Berg, Fl. bras. 14(1): 39. 1857.

Arvoreta 1,8 m alt., súber destacado do ramo no material seco, nós foliares com protuberância, gemas vegetativas tomentosas. Lâmina foliar 21-27,5 × 5,4-9 cm, coriácea, oblonga, ápice arredondado, base obtusa, pilosidade ocrácea; face adaxial glabrescente a glabra, pontuações impressas, nervura central sulcada, nervuras laterais levemente salientes, numerosas; face abaxial tomentosa a glabrescente, pontuações inconspícuas, nervura central saliente, nervuras laterais levemente salientes, numerosas; pecíolo $1-1,8 \mathrm{~cm}$ compr., canaliculado, glabrescente a glabro. Inflorescência ca. $11 \mathrm{~cm}$ compr., multiflora, terminal. Brácteas não vistas. Bractéolas ca. 1,5 $\mathrm{mm}$ compr., lineares, ápice acuminado, base truncada, tomentosas. Botão floral levemente rostrado. Hipanto tomentoso externamente, ápice prolongado sobre o ovário; cálice ca. $2 \mathrm{~mm}$ compr., externamente tomentoso, internamente glabro; pétalas ausentes; estames de filetes glabros, anteras quadradas; estilete cilíndrico, glabro. Fruto não visto.

Material examinado: 8.I.2006, M.F. Santos et al. 58 (SPF).

Material adicional examinado: BRASIL. MINAS GERAIS: Alfenas, fazenda Ilha, 20.II.1982, fl., M.C.W. Vieira 281 (SPF). 
Calyptranthes clusiifolia se distingue pela combinação da ramificação dicotômica, lâmina foliar oblonga, 21-27,5 × 5,4-9 cm e antese por caliptra. Na Serra do Ouro Branco foi coletada apenas estéril, de modo que não foi possível obter nenhum dado de floração ou frutificação. Na região, habita os capões de mata. Ocorre nos estados de Alagoas, Espírito Santo, Goiás, Minas Gerais, Pernambuco, São Paulo e Sergipe (Sobral et al. 2012).

3.2. Calyptranthes pulchella DC., Prod. 3: 257. 1828.

Fig. $2 b$

Arvoreta ca. $2 \mathrm{~m}$ alt., caule levemente fissurado, ramos glabros, pequenas quilhas nos ramos imaturos. Lâmina foliar 1,6-2,5 × 1-1,5 cm, sub-coriácea, obovada, ápice arredondado, base aguda, margem revoluta, glabra; face adaxial com pontuações impressas, nervura central impressa, nervuras laterais inconspícuas; face abaxial com pontuações salientes, nervura central saliente, nervuras laterais inconspícuas; pecíolo $2-3 \mathrm{~mm}$ compr., canaliculado, glabro. Inflorescência 1,5-3 cm compr., multiflora, terminal. Brácteas e bractéolas não vistas. Botão floral ca. 3 mm compr., globoso levemente rostrado. Bractéolas não vistas. Hipanto glabro externamente, ápice prolongado sobre o ovário; cálice ca. $1 \mathrm{~mm}$ compr., externamente glabro, internamente glabro; pétalas ausentes; estames de filetes glabros, anteras quadradas; estilete cilíndrico, glabro. Fruto não visto.
Material examinado: 9.I.2006, M.F. Santos et al. 87 (SPF).

Material adicional examinado: BRASIL. BAHIA: Rio de Contas, Pico das Almas, 28.XI.1988, fl., R.M. Harley et al. 26646 (CEPEC, G, K, MAM, NY, SP, SPF).

Calyptranthes pulchella compartilha com C. clusiifolia a ramificação dicotômica e a antese por caliptra, mas se distingue pela lâmina foliar obovada, 1,6-2,5 × 1-1,5 cm, apresentando ainda os ramos mais delgados. Na Serra do Ouro Branco foi coletada apenas estéril, de modo que não foi possível obter nenhum dado de floração ou frutificação. Na região, habita o sub-bosque dos capões de mata. No Brasil, ocorre nos estados do Acre, Amazonas, Bahia, Espírito Santo, Maranhão, Minas Gerais e Rio de Janeiro (Sobral et al. 2012).

\section{Campomanesia Ruiz \& Pav.}

Arbustos a árvores; ramificação monopodial. Inflorescência 1-flora. Bractéolas decíduas. Flor 5-mera; cálice aberto no botão floral; ovário 4-18-locular, lóculo glandular formando uma pseudotesta na semente, 4-20- ovulado, estigma capitado. Fruto coroado pelos lobos do cálice; semente 1-4 por fruto; embrião com radícula alongada ou espiralada e cotilédones pequenos e foliáceos (embrião mirtoide).

Gênero composto por aproximadamente 30 espécies distribuídas na América do Sul, com centro de diversidade na Mata Atlântica (Landrum 1986).

\section{Chave para identificação das espécies de Campomanesia da Serra do Ouro Branco}

1. Plantas essencialmente glabras, exceto pelas gemas vegetativas; lâmina foliar de base cordada 4.1. C. adamantium

1'. Plantas com pilosidade conspícua; lâmina foliar de base aguda a obtusa 4.2. C. pubescens

\subsection{Campomanesia adamantium (Cambess.)} O.Berg, Linnaea 27: 434. 1856.

Arbusto, altura desconhecida, essencialmente glabro, exceto pelas gemas vegetativas, ramos imaturos com pontuações esparsas. Lâmina foliar 2-3,9 × 1,4-1,7 cm, cartácea, ovada, ápice agudo a acuminado, base cordada, nervura marginal não-definida; face adaxial com pontuações inconspícuas, nervação impressa; face abaxial com pontuações impressas, nervura central saliente, nervuras laterais impressas; pecíolo sub-séssil, canaliculado. Inflorescência com brácteas iguais às folhas. Pedicelo 1,1-1,8 cm compr, achatado. Bractéolas 2-4 mm compr., lineares a linearlanceoladas, ápice acuminado, margem ciliada, pontuações salientes. Botão floral ca. $5 \mathrm{~mm}$ compr., globoso. Flor com hipanto glabro externamente, não verrucoso-glandular, ápice não-prolongado sobre o ovário; lobos do cálice ca. $2 \mathrm{~mm}$ compr., suborbiculares, ápice arredondado, margem ciliada, externamente verrucoso-glandular; pétalas ca. 6 $\mathrm{mm}$ compr., obovadas, margem ciliada; estames de filetes glabros, anteras oblongas; estilete cilíndrico, glabro. Fruto não visto. 
Material examinado: 1.X.1988, fl., A.P. Lage (BHCB 14470).

Campomanesia adamantium pode ser reconhecida por apresentar folhas de base cordada, não encontrada até o momento em outros espécimes da Serra do Ouro Branco. Dentro do gênero, as estruturas glabras são características distintivas da espécie. O exemplar citado foi coletado no mês de outubro em plena floração. Na ficha não há indicação do habitat, mas segundo Landrum (1986), a espécie é encontrada em "campos" e "cerrados" dos estados brasileiros de Goiás, Mato Grosso, Minas Gerais, Paraná, Santa Catarina e São Paulo, além de ocorrer no Paraguai.

\subsection{Campomanesia pubescens (DC.) O.Berg,} Linnaea 27: 429. 1856.

Fig. 2c

Subarbustos $55-85 \mathrm{~cm}$ alt., ramos imaturos pubescentes, pontuações presentes, ramos maduros glabrescentes. Lâmina foliar 2,6-7,7 × 1,1-3,8 $\mathrm{cm}$, cartácea, obovada, ovada ou elíptica, ápice agudo, obtuso ou arredondado, base aguda a obtusa, nervura marginal não-definida; face adaxial pubescente a pubérula, pontuações salientes, nervação impressa a bulada; face abaxial pubérula a glabra ou tomentosa, pontuações salientes, densamente ou não, nervação saliente; pecíolo 3-8 $\mathrm{mm}$, canaliculado, pubescente. Inflorescência 1-flora, axilar. Pedicelo 1-3,8 $\mathrm{cm}$ compr., achatado, pubescente. Bractéolas 3,5-8 $\mathrm{mm}$ compr., lineares a estreitamente elípticas, ápice acuminado, externamente pubérula com pontuações, internamente pubescente. Botão floral ca. 7,5 mm compr., globoso. Flor com hipanto glabro, pubescente ou tomentoso externamente, verrucoso-glandular, ápice não-prolongado sobre o ovário; lobos do cálice 4-4,5 mm compr., amarelo-esverdeados, suborbiculares ou oblongos, ápice obtuso ou arredondado, base fusionada, externamente pubérulos a glabros ou tomentosos, verrucoso-glandulares, internamente pubescentes ou tomentosos; pétalas ca. $7 \mathrm{~mm}$ compr., alvas a róseas, suborbiculares ou obovadas, externamente com tricomas esparsos ou glabras, internamente glabras, pontuações impressas; estames de filetes glabros, anteras oblongas; ovário 8-locular, óvulos ca. 24, ca. 4-7 por lóculo, estilete cilíndrico, glabro. Fruto imaturo globoso, glabrescente; semente 3-5 por fruto.

Material selecionado: 2.X.1988, fr., Y.M. Alves (BHCB 14354); 21.X.1988, f1., M.M.N. Braga 273 (BHCB); 1.X.1988, f1., A.P. Lage (BHCB 14467); 2.X.1988, fl., K. Marques (BHCB 13909); 9.VI.2002, fl., C.C. Paula et al. 57 (SPF, VIC); 22.VI.2002., fl., C.C. Paula et al. 113 (SPF, VIC); 24.VII.1987, fl., J.R. Pirani et al. CFCR 11205 (MBM, RB, SPF); 13.IX.1989, fl., M.G.V. Torquato et al. (BHCB 17307).

Campomanesia pubescens é, às vezes, morfologicamente similar à $C$. adamantium, distinguindo-se, principalmente, pelo indumento conspícuo; além disso, a base foliar cordada não ocorre em C. pubescens (Landrum 1986). Plantas em antese apresentando apenas folhas imaturas é também um caráter distintivo da espécie. $\mathrm{Na}$ Serra do Ouro Branco, foi encontrada com flores em junho, setembro e outubro. Habita os afloramentos rochosos e os campos graminoides da área. Sua distribuição engloba os campos do Distrito Federal, dos estados da Bahia, Goiás, Mato Grosso, Mato Grosso do Sul, Minas Gerais, Paraná e São Paulo, incluindo também o Paraguai (Landrum 1986).

\section{Eugenia P.Micheli ex L.}

Árvores ou arbustos; ramificação monopodial. Flores solitárias ou reunidas em racemos, frequentemente com o eixo principal reduzido formando fascículos. Bractéolas em geral persistentes. Flor 4-mera; cálice aberto no botão floral; ovário 2-locular, muitos óvulos axilares por lóculo, estigma punctiforme. Fruto coroado pelos lobos do cálice; sementes 1-2; embrião com radícula inconspícua e cotilédones desenvolvidos, carnosos (embrião eugenioide).

Gênero com distribuição do México até o norte da Argentina, passando pelo Caribe (Landrum \& Kawasaki 1997). Conta com mais de 550 espécies (Govaerts et al. 2006).

\section{Chave para identificação das espécies de Eugenia da Serra do Ouro Branco}

1. Subarbusto; lâmina foliar coriácea; pedicelo 1-5 mm compr.; bractéolas largamente ovadas; lobos do cálice arredondados ou ovados a depresso-ovados 5.1. E. bimarginata

1'. Arvoreta; lâmina foliar cartácea; pedicelo ca. $2 \mathrm{~cm}$ compr.; bractéolas triangulares; lobos do cálice triangulares 5.2. E. ligustrina 
5.1. Eugenia bimarginata DC., Prodr. 3: 271. 1828.

Fig. $2 d$

Subarbusto ca. $0,5 \mathrm{~m}$ alt., xilopódio às vezes presente, caule fissurado, ramos glabros. Lâmina foliar 3,6-7,2 × 1,4-3,6 cm, coriácea, elíptica a obovada, ápice obtuso a arredondado, base aguda (raramente obtusa ou arredondada), margem revoluta ou plana, glabra, pontuações presentes (poucas a numerosas), ambas faces com nervação saliente, nervura marginal dupla; pecíolo subsséssil ou menor que $3 \mathrm{~mm}$ compr., canaliculado, glabro. Inflorescência 1-3-flora, fascicular, axilar. Pedicelo 1-5 mm compr., glabro, achatado a cilíndrico. Bractéolas 0,1-2,4 mm compr., largamente ovadas, côncavas, ápice obtuso, glabras, externamente com pontuações salientes. Botão floral ca. 4,5 mm compr., globoso. Flor com hipanto glabro externamente, pontuações presentes ou inconspícuas, ápice não-prolongado sobre o ovário; lobos do cálice ca. $1,8 \mathrm{~mm}$ compr., orbiculares ou ovados a depresso-ovados, côncavos, ápice arredondado, glabros ou ciliados, pontuações presentes ou inconspícuas; pétalas ca. 1,3 mm compr., alvoesverdeadas, orbiculares, côncavas, levemente ciliadas, externamente pontuações presentes; estames de filetes glabros, anteras oblongas a lanceoladas; ovário com vários óvulos por lóculo, estilete cilíndrico, glabro. Fruto globoso, glabro, pontuações inconspícuas; sementes não vistas.

Material selecionado: 29.VII.1988, fr., M.M.N. Braga et al. (BHCB 13684); 28.V.1997, fr., M.L. Kawasaki 1007 (SPF); 9.I.2006, fl., M.F. Santos et al. 66 (SPF, VIC); 8.III.1995, fr., V.C. Souza et al. 7926 (ESA, SPF).

Eugenia bimarginata distingue-se pelas folhas coriáceas de nervura marginal dupla e inflorescência em fascículos ao longo dos ramos (Kawasaki 1989). Em Ouro Branco, foi vista em floração no mês de janeiro e julho, habitando os campos graminoides da área. A distribuição da espécie se dá pelos cerrados, campos rupestres e matas de Bahia, Goiás, Mato Grosso, Mato Grosso do Sul, Minas Gerais, São Paulo e Paraná (Sobral et al. 2012).

5.2. Eugenia ligustrina (Sw.) Willd., Sp. Pl. 2: 962. 1799.

Fig. 2e

Arvoreta ca. $2 \mathrm{~m}$ alt., caule fissurado, ramos glabros; catáfilos côncavos, ovados na base, glabros e decíduos. Lâmina foliar 4,7-8,8 × 1,1-2,5 $\mathrm{cm}$, cartácea, elíptica, ápice agudo a acuminado, base aguda a estreitamente aguda, margem revoluta, glabra; face adaxial com pontuações impressas, nervura central sulcada, nervuras laterais levemente proeminentes, sinuosas; face abaxial com numerosas pontuações impressas a salientes, nervura central saliente, nervuras laterais inconspícuas; pecíolo 3-4 mm compr., canaliculado, glabro a piloso. Inflorescência 2-3-flora, axilar ou terminal, glabra, catáfilos na base. Pedicelo ca. $2 \mathrm{~cm}$, glabro, cilíndrico. Bractéolas ca. 0,3 mm compr., triangulares, planas, ápice agudo, glabras. Botão floral ca. 6 $\mathrm{mm}$ compr., globoso. Flor com hipanto glabro externamente, pontuações inconspícuas, ápice não-prolongado sobre o ovário; lobos do cálice ca. 3,1 mm compr., triangulares, planos, ápice agudo, glabros, externamente pontuações salientes; pétalas ca. 8,3 mm compr., obovadas, glabras, pontuações salientes, raras; estames de filetes glabros, anteras globosas; ovário com lóculo multi-ovulado, estilete cilíndrico, glabro. Fruto não visto.

Material examinado: 21.X.1988, fl., M.B. Horta et al. 364 (BHCB, SPF); 9.I.2006, M.F. Santos et al. 79 (SPF, VIC).

Eugenia ligustrina pode ser diferenciada por apresentar inflorescência com catafilos na base e pedicelo com ca. de $2 \mathrm{~cm}$ de comprimento. Coletada em floração no mês de outubro, a espécie é registrada pela primeira vez em área de campo rupestre, habitando um capão de mata. Sua distribuição se estende do Caribe ao Brasil, onde ocorre nos estados do Ceará, Espírito Santo, Minas Gerais, Pará, Paraíba, Paraná, Pernambuco, Piauí, Rio de Janeiro, Rio Grande do Norte, São Paulo e Sergipe (Govaerts et al. 2006; Sobral et al. 2012).

\section{Marlierea Cambess.}

Árvores ou arbustos; ramificação geralmente monopodial. Inflorescências em panículas. Bractéolas decíduas ou persistentes. Flor 4-5-mera; cálice em geral parcialmente fechado no botão floral, lobos geralmente irregulares na antese; ovário 2-locular, lóculo 2-ovulado, estigma puntiforme. Fruto coroado pelos lobos do cálice ou por uma cicatriz circular; sementes 1-2 por fruto; embrião com radícula alongada e cotilédones desenvolvidos, foliáceos e dobrados (embrião mircioide).

Gênero com cerca de 50 espécies, distribuídas predominantemente na América do Sul, mas ocorrendo também na América Central e Caribe. Segundo análises filogenéticas recentes, o gênero não é monofilético (Lucas et al. 2011). 


\section{Chave para identificação das espécies de Marlierea da Serra do Ouro Branco}

1. Plantas essencialmente glabras; lâmina foliar 1,4-2,6 × 0,3-0,4 cm

6.1. M. angustifolia

1'. Plantas com pilosidade conspícua, avermelhada; lâmina foliar 7-10 × 2,4-3,2 cm .... 6.2. M. clausseniana

6.1. Marlierea angustifolia (O. Berg) Mattos, $\mathrm{Ci}$. \& Cult. 19: 333. 1967.

Fig. $2 f$

Arbusto 1,5-2,5 m alt., ramos glabros, pontuações presentes nos ramos imaturos. Lâmina foliar 1,4-2,6×0,3-0,4 cm, cartácea, estreitamente elíptica, ápice arredondado, base aguda, margem levemente revoluta, glabra (raramente com tricomas esparsos nas folhas imaturas), quando imatura verrucosa-glandular; face adaxial com pontuações impressas, nervura central levemente depressa na base e impressa no ápice, nervuras laterais inconspícuas; face abaxial com pontuações impressas a salientes, nervura central saliente, nervuras laterais inconspícuas; pecíolo sub-séssil, canaliculado, glabro. Inflorescência ca. $1 \mathrm{~cm}$ compr., pauciflora (1-5-flora), axilar, raras vezes terminal; ráquis achatada, glabra. Brácteas e bractéolas não vistas. Botão floral ca. 1,8 mm compr., turbinado. Flor 4-mera; hipanto glabro externamente, verrucoso-glandular, ápice ca. $1 \mathrm{~mm}$ prolongado sobre o ovário; cálice aberto no botão floral, lobos ca. 0,5-1 mm compr., regulares, decíduos após a antese, suborbiculares a depresso-ovados, ápice arredondado, glabros, verrucoso-glandulares ou apenas pontuações salientes; pétalas ca. $2 \mathrm{~mm}$ compr., alvas, orbiculares, glabras, externamente com pontuações salientes; estames de filetes glabros, anteras quadradas a transversalmente oblongas; estilete cilíndrico, glabro. Fruto não visto.

Material selecionado: 9.I.2006, fl., M.F. Santos et al. 69 (BHCB, SPF, VIC).

Marlierea angustifolia distingue-se das outras espécies do gênero pelas folhas pequenas $(1,4-2,6 \times 0,3-0,4 \mathrm{~cm})$ e glabras, pela inflorescência pauciflora e pelos lobos do cálice decíduos na antese. Foi coletada, em Ouro Branco, em plena antese no mês de janeiro, na borda de capão de mata. Ocorre nos estados de Minas Gerais, Rio de Janeiro e São Paulo (Sobral et al. 2012).

6.2. Marlierea clausseniana (O.Berg) Kiaersk., Enum. Myrt. Bras.: 51. 1893.

Árvore, altura desconhecida, ramos imaturos com pilosidade avermelhada, pontuações salientes, ramos maduros glabros. Lâmina foliar 7-10 × 2,4-3,2 cm, subcoriácea, elíptica, ápice acuminado, base cuneada, margem plana; face adaxial glabra, pontuações impressas, numerosas, nervura central sulcada, nervuras laterais inconspícuas; face abaxial com tricomas avermelhados apenas na nervura central, pontuações salientes, numerosas, nervura central saliente, nervuras laterais impressas, numerosas; pecíolo ca. $1 \mathrm{~cm}$ compr., canaliculado, pilosos. Inflorescência ca. $5 \mathrm{~cm}$ compr., multiflora, subterminal; ráquis achatada, com pilosidade avermelhada. Brácteas e bractéolas não vistas. Botão floral ca. 2,5 mm compr., campanulado. Flor 4-mera; hipanto piloso externamente, verrucoso-glandular, ápice ca. 1,5 $\mathrm{mm}$ prolongado sobre o ovário; cálice aberto no botão floral, lobos regulares, persistentes ou decíduos, ca. 0,5 mm compr., suborbiculares, ápice arredondado, pilosos, pontuações salientes; pétalas ca. 1,5 mm compr., oblongas, externamente pilosas, pontuações salientes, internamente glabras; estames de filetes glabros, anteras quadradas; estilete cilíndrico, glabro. Fruto não visto.

Material examinado: 1.X.1988, fl., A.R. Miranda et al. (BHCB 13945).

Marlierea clausseniana distingue-se pela pilosidade avermelhada e pela folha densamente coberta por pontuações translúcidas. Na Serra do Ouro Branco foi coletado um espécime em floração no mês de outubro, em capão de mata. A espécie distribui-se pelos estados da Bahia, Espírito Santo e Minas Gerais (Sobral et al. 2012).

\section{Myrceugenia $\mathrm{O}$. Berg}

Árvores ou arbustos; ramificação monopodial. Inflorescência 1-flora ou pedicelos superpostos nas axilas das folhas ou brácteas. Bractéolas em geral persistentes até o fruto maduro. Flores 4-meras; cálice em geral aberto no botão floral; ovário 2-4-locular, lóculo 2-20-ovulado, estigma punctiforme. Fruto coroado pelos lobos do cálice; semente 1-5 por fruto; embrião com radícula alongada e cotilédones desenvolvidos, foliáceos e dobrados (embrião mircioide).

Gênero de distribuição disjunta entre o leste da América do Sul, onde ocorre principalmente em áreas de clima subtropical de altitude, e a porção centro-sul do Chile, sob clima subtropical. Conta com cerca de 40 espécies (Landrum 1981). 


\section{Chave para identificação das espécies de Myrceugenia da Serra do Ouro Branco}

1. Pilosidade ocrácea; pedicelo 2-5,1 mm compr.; bractéolas largamente ovadas; botão floral obcônico ... 7.1. M. alpigena

1'. Pilosidade ferrugínea; pedicelo subssésil-2 mm compr.; bractéolas lineares a lanceoladas; botão floral rômbico 7.2. Myrceugenia aff. pilotantha

7.1. Myrceugenia alpigena (DC.) Landrum, Brittonia 32(3): 372. 1980.

Fig. 3a

Arvoreta ca. $1,5 \mathrm{~m}$ alt., pilosidade ocrácea, tricomas dibraquiados ocráceos, ramos imaturos tomentosos, ramos maduros glabros. Lâmina foliar 3,6-8 × 1,9-3,3 cm, discolor, subcoriácea, elíptica, obovada ou ovada, ápice obtuso ou arredondado, base aguda, margem plana, pontuações inconspícuas em ambas as faces; face adaxial imatura tomentosa, quando madura glabra, nervura central sulcada, impressa, nervuras laterais inconspícuas ou levemente salientes; face abaxial tomentosa quando imatura, glabrescente quando madura, nervura central saliente, nervuras laterais levemente salientes ou inconspícuas; pecíolo 4-7 mm compr., canaliculado, tomentoso. Inflorescência 1-flora ou até quatro pedicelos superpostos, axilar. Pedicelos 2-5,1 mm compr., achatados, tomentosos. Bractéolas alcançando da metade até quase o comprimento total do botão floral, persistentes, largamente ovadas, ápice obtuso, pontuações impressas, externamente tomentosas, internamente glabras. Botão floral ca. $4 \mathrm{~mm}$ compr., obcônico. Flor com hipanto tomentoso externamente, ápice não-prolongado sobre o ovário; lobos do cálice ca. 2,3 mm compr., suborbiculares, ápice obtuso, tomentosos; pétalas ca. 3,5 mm compr., largamente obovadas, glabras, pontuações presentes; estames de filetes glabros, com anteras oblongas a lanceoladas; ovário 3-locular, estilete cilíndrico, com tricomas esparsos. Fruto globoso, tomentoso a glabrescente, pontuações salientes; cálice com lobos patentes; semente não vistas.

Material examinado: 9.I.2006, fl., M.F. Santos et al. 64 (BHCB, F, K, SPF, VIC).

Myrceugenia alpigena pode ser reconhecida pelos pedicelos superpostos na axila foliar e pelas bractéolas largamente ovadas, aderidas à flor. Segundo Landrum (1981), este espécime se enquadraria em $M$. alpigena var. rufa (O.Berg) Landrum, que ocorre desde Minas Gerais até o sul do Brasil, sendo caracterizada pela densa pilosidade e pelos lobos do cálice arredondados e maiores que o hipanto. Na Serra do Ouro branco foi encontrada em floração em janeiro, na borda de um capão de mata, habitat comum para a espécie (Landrum 1981). A espécie ocorre na Bahia, Distrito Federal, Espírito Santo, Minas Gerais, Paraná, Rio de Janeiro, Rio Grande do Sul e Santa Catarina (Landrum 1981).

\subsection{Myrceugenia aff. pilotantha (Kiaersk.)} Landrum, Brittonia 32: 374.1980. Fig. 2g-h

Arvoreta ca. $2 \mathrm{~m}$ alt., pilosidade ferrugínea, tricomas simples e dibraquiados ferrugíneos, ramos fissurados, quando imaturos tomentosos, quando maduros glabros. Lâmina 2,1-5,1 × 0,8-2,1 cm, cartácea, elíptica a obovada, ápice obtuso a arredondado, base aguda, margem plana; face adaxial glabra, pontuações impressas, nervura central sulcada, nervuras laterais inconspícuas; face abaxial tomentosa quando jovem, pubérula quando madura, pontuações impressas, nervação saliente; pecíolo 2-4 mm compr., canaliculado, piloso. Inflorescência 1-flora, axilar, às vezes subterminal. Pedicelo subséssil-2 mm compr., canaliculado, tomentoso. Bractéolas alcançando mais da metade a maiores que o comprimento do botão floral, persistentes, lineares a lanceoladas, côncavas a quase canaliculadas, ápice arredondado, pontuações impressas, externamente tomentosa, internamente pilosa a glabra. Botão floral ca. 4,2 mm compr., rômbico. Flor com hipanto tomentoso externamente, ápice não-prolongado sobre o ovário; lobos do cálice ca. 2,3 mm compr., triangulares, ápice agudo, tomentosos; pétalas ca. $2 \mathrm{~mm}$ compr., orbiculares, glabras, pontuações impressas; estames de filetes glabros, anteras com tecas desiguais; ovário 3-locular, lóculo 2-4-ovulado, estilete cilíndrico, glabro. Fruto globoso, glabrescente; cálice com lobos patentes; semente não vistas.

Material selecionado: 9.I.2006, fl., M.F. Santos et al. 73 (K, SPF, VIC).

Myrceugenia pilotantha se caracteriza pelo botão floral rômbico e, assim como M. alpigena, possui bractéolas aderidas à flor, mas, como destacado na chave, diferencia-se pela forma das bractéolas. Segundo Landrum (1981), M. pilotantha possui pétalas externamente pubescentes e ocorre nas matas do Rio Grande do Sul ao Rio de Janeiro, 




Figura 3 - a. Myrceugenia alpigena -inflorescência e botões florais. b. Myrcia eriocalyx - ramo, inflorescências e botões florais. c. Myrcia retorta - face abaxial da folha. d-e. Myrcia splendens - d. face abaxial da folha; e. fruto imaturo. f-g. Myrcia subverticillaris -f. ramo florífero; g. fruto imaturo. h. Siphoneugena crassifolia - inflorescência e flores após antese (a. M.F. Santos 64; b. M.F. Santos 84; c. M.F. Santos 94; d. M.F. Santos 67; e. M.F. Santos 67; f. M.F. Santos 65; g. M.F. Santos 65; h. A. Furlan CFSC 6456). Figure 3 - a. Myrcengenia alpigena -inflorescence and flowers buds. b. Myrcia eriocalyx - branch, inflorescences and flowers buds. c. Myrcia retorta -leaf abaxial surface. d-e. Myrcia splendens - d. leaf abaxial surface; e. imature fruit. f-g. Myrcia subverticillaris - f. flowering branch; g. imature fruit. h. Siphoneugena crassifolia - inflorescence and flowers after anthesis (a. M.F. Santos 64; b. M.F. Santos 84; c. M.F. Santos 94; d. M.F. Santos 67; e. M.F. Santos 67; f. M.F. Santos 65; g. M.F. Santos 65; h. A. Furlan CFSC 6456). 
sempre próxima ao litoral. Com exceção destes dados, as características dos materiais coletados condizem com a descrição da espécie, mas, devido às contradições citadas, optou-se por identificá-los como Myrcengenia aff. pilotantha. Na Serra do Ouro Branco foi encontrada em floração em janeiro, no sub-bosque de capão de mata.

\section{Myrcia DC. ex Guill.}

Árvores, arbustos ou subarbustos; ramificação monopodial ou simpodial. Inflorescências em panículas, raramente paucifloras. Bractéolas decíduas. Flor 5-mera; cálice aberto no botão floral; ovário 2-4 locular, lóculo 2-ovulado, estigma punctiforme. Fruto coroado pelos lobos do cálice ou por uma cicatriz circular; sementes 1-2; embrião com radícula alongada e cotilédones desenvolvidos, foliáceos e dobrados (embrião mircioide).

Gênero de distribuição neotropical, desde o México até o norte da Argentina, passando pelo Caribe. Apresenta 250-500 espécies (Landrum \& Kawasaki 1997; Govaerts et al. 2006). Segundo análises filogenéticas recentes, o gênero não é monofilético (Lucas et al. 2011).

\section{Chave para identificação das espécies de Myrcia da Serra do Ouro Branco}

1. Folhas predominantemente glabras.

2. Lâmina foliar coriácea, ápice emarginado a arredondado, face adaxial com nervura central impressa a saliente, pecíolo rubro; cálice patente no fruto 8.5. M. obovata

2'. Lâmina foliar cartácea, ápice agudo a acuminado, face adaxial com nervura central sulcada, pecíolo verde; cálice reflexo no fruto.

3. Lâmina foliar com base obtusa, face adaxial com nervuras laterais inconspícuas; anteras quadradas

3'. Lâmina foliar com base retusa, face adaxial com nervuras laterais impressas; anteras oblongas 8.4. M. laruotteana

1'. Folhas com indumento conspícuo.

4. Ápice do hipanto não-prolongado sobre o ovário.

5. Caule tortuoso; lâmina foliar com face abaxial tomentosa desigualmente glabrescente; ovário 4-locular 8.6. M. retorta

5'. Caule reto; lâmina foliar com face abaxial hispídula, serícea a serícea-pubescente, tomentosa ou pubérula; ovário 2-locular.

6. Ramos imaturos híspidos; lâmina foliar com face abaxial hispídula; panícula com ráquis híspida 8.3. M. eriopus

6'. Ramos imaturos seríceos; lâmina foliar com face abaxial serícea a serícea-pubescente, tomentosa ou pubérula; panícula com ráquis pubérula ou tomentosa

8.7. M. splendens

4'. Ápice do hipanto prolongado sobre o ovário.

7. Ramos imaturos, folhas e ráquis da inflorescência com pilosidade híspida; inflorescência pauciflora 8.2. M. eriocalyx

7'. Ramos imaturos, folhas e ráquis da inflorescência glabros, glabrescentes, com tricomas esparsos ou com pilosidade pubérula, tomentosa ou vilosa; inflorescência multiflora.

8. Filotaxia suboposta, alterna ou verticilada; lâmina foliar com ápice arredondado ou emarginado; face adaxial com nervura central saliente, nervuras laterais inconspícuas

8.8. M. subverticillaris

8'. Filotaxia oposta; lâmina foliar com ápice agudo a obtuso; face adaxial com nervura central impressa a sulcada, nervuras laterais impressas a salientes.

9. Caule descamante; lâmina foliar pilosidade amarelada, nervação lateral curva; pecíolo 0,8-1,4 cm compr.; inflorescência apenas com flores sésseis

9'. Caule sem descamação acentuada; lâmina foliar com pilosidade ferrugínea, nervação lateral densamente reticulada; pecíolo 2-7 mm compr.; inflorescência com flores sésseis e pediceladas 8.10. M. venulosa 
8.1. Myrcia amazonica DC., Prodr. 3: 250. 1828.

Arvoreta ca. 2,5 m alt., ramos imaturos com tricomas esparsos, ramos maduros avermelhados, glabros. Lâmina foliar 3,2-7,4 × 1,3-3,2 cm, cartácea, elíptica, ápice agudo, base obtusa, margem plana, glabra (raramente com tricomas esparsos); face adaxial com pontuações numerosas e impressas, nervura central sulcada, nervuras laterais inconspícuas; face abaxial com pontuações salientes, nervação saliente, reticulada; pecíolo 3-5 mm compr., verde, canaliculado, glabro. Inflorescência ca. 5-9,1 cm compr., multiflora, subterminal; ráquis achatada, pilosa. Brácteas, bractéolas e botão floral não vistos. Hipanto tomentoso a glabrescente externamente, verrucosoglandular, ápice ca. $0,5 \mathrm{~mm}$ prolongado sobre o ovário; lobos do cálice ca. $0,6 \mathrm{~mm}$ compr., ovadotriangulares, externamente glabrescentes, pontuações salientes, internamente pilosos a glabros; pétalas não vistas; estames de filetes glabros, anteras quadradas; ovário não visto, estilete cilíndrico, glabro. Fruto imaturo verde, globoso, piloso, verrucoso-glandular; cálice reflexo; semente 2 por fruto, testa crustácea.

Material examinado: 9.I.2006, fr., M.F. Santos et al. 83 (BHCB, SPF, VIC).

Myrcia amazonica destaca-se pelos ramos avermelhados e pelas folhas castanho-avermelhadas no material seco, com as nervuras laterais inconspícuas na face adaxial. Espécime encontrado em final de frutificação em janeiro, habitando a borda de capão de mata. Distribui-se por toda América Tropical (Govaerts et al. 2006).

\subsection{Myrcia eriocalyx DC., Prod. 3: 247. 1828.}

Fig. $3 b$

Arbusto 1-1,5 $\mathrm{m}$ alt., pilosidade ferrugínea, ramos imaturos híspidos, ramos maduros glabrescentes. Lâmina foliar 1,9-3,2 × 0,9-1,2 cm, cartácea a sub-coriácea, elíptica, ápice obtuso, base obtusa, margem revoluta, mais fortemente na base; face adaxial hispídula a glabrescente, pontuações impressas, nervura central sulcada, nervuras laterais salientes ou impressas, reticuladas; face abaxial híspida a hispídula, pontuações salientes, nervura central saliente, nervuras laterais inconspícuas a levemente salientes; pecíolo subséssil, canaliculado, híspido. Inflorescência ca. 2,3-4,3 cm compr., pauciflora, axilar; ráquis cilíndrica, híspida. Brácteas ca. 6,2 mm compr., lanceoladas, côncavas, ápice agudo, base truncada, externamente híspidas, internamente glabras. Bractéolas ca. 3,3 mm compr., iguais às brácteas, apenas mais estreitas. Botão floral ca. 4,6 mm compr., rômbico, cálice corniculado. Hipanto híspido externamente, ápice $0,3 \mathrm{~mm}$ prolongado sobre ovário; lobos do cálice ca. 2,1 mm compr., esverdeados, estreitamente triangulares, ápice acuminado, externamente híspidos, internamente pilosos, pontuações inconspícuas; pétalas ca. $3 \mathrm{~mm}$ compr., orbiculares, externamente hispídulas, pontuações inconspícuas, internamente glabras, pontuações como manchas escuras; estames de filetes glabros, anteras oblongas; ovário 2-locular, estilete cilíndrico, tricomas longos, pontuações aparecendo como manchas escuras. Fruto globoso, glabrescente, cálice patente.

Material examinado: 21.X.1988, fr., M.B. Horta et al. 373 (BHCB); 8.I.2006, fl., M.F. Santos et al. 57 (BHCB, SPF, VIC); 9.I.2006, fl., M.F. Santos et al. 84 (SPF, VIC).

Myrcia eriocalyx é facilmente caracterizada pela pilosidade híspido-ferrugínea distribuída por toda a planta, juntamente com a inflorescência pauciflora. Na Serra do Ouro Branco foi coletada nos campos e nas bordas de capão de mata, florescendo em janeiro e frutificando em outubro. Ocorre nos estados da Bahia, Espírito Santo e Minas Gerais (Sobral et al. 2012).

8.3. Myrcia eriopus DC., Prodr. 3: 255. 1828.

Arvoreta, altura desconhecida, caule reto, ramos imaturos híspidos, ramos maduros glabrescentes. Lâmina foliar 4-8,3 × 1,2-3,3 cm, cartáceas, ovada a lanceolada, ápice acuminado, base obtusa, margem plana; face adaxial glabra exceto pela nervura central, pontuações impressas, nervura central sulcada, nervuras laterais salientes; face abaxial hispídula, pontuações impressas, nervação saliente; pecíolo ca. $3 \mathrm{~mm}$ compr., canaliculado, híspido. Inflorescência 2,5-4 cm compr., pauciflora, axilar; ráquis achatada, híspida. Brácteas não vistas. Bractéolas ca. $3 \mathrm{~mm}$ compr., estreitamente triangulares, planas, ápice agudo, base truncada, externamente híspidas, pontuações salientes. Botão floral ca. 2,5 mm compr., globoso. Hipanto híspido externamente, ápice não-prolongado sobre o ovário; lobos do cálice ca. 1,5 mm compr., suborbiculares, externamente híspidos, verrucoso-glandulares, internamente glabros, verrucoso-glandulares; pétalas ca. 1,5 mm compr., obovadas, externamente seríceas na porção mediana, pontuações salientes, internamente glabras; estames de filetes glabros, anteras com tecas às vezes assimétricas; ovário 2-locular, estilete cilíndrico, glabro. Fruto não visto. Material examinado: 1.X.1988, fl., J.G. Vaz (BHCB 14366).

Myrcia eriopus, assim com M. eriocalyx, apresenta pilosidade híspida e inflorescência pauciflora, diferenciando-se pelo tamanho (4-8,3 
$\times$ 1,2-3,3 cm) e forma da lâmina foliar (ovada a lanceolada). $\mathrm{O}$ espécime foi coletado em área de mata, florescendo no mês de outubro. No Brasil, ocorre em Goiás, Minas Gerais, Rio de Janeiro e São Paulo (Sobral et al. 2012).

8.4. Myrcia laruotteana Cambess., Fl. Bras. Merid. 2: 311. 1832.

Arvoreta ca. $2 \mathrm{~m}$ alt., ramos glabros, lenticelas presentes. Lâmina foliar 3,3-7 × 1,2-2,9 cm, cartácea, elíptica, ápice agudo a acuminado, base retusa (raramente obtusa), margem ondulada quando seca, tricomas esparsos; face adaxial com pontuações impressas, nervura central sulcada, nervuras laterais inconspícuas; face abaxial com pontuações impressas a salientes, nervura central saliente, nervuras laterais inconspícuas; pecíolo $2-5 \mathrm{~mm}$ compr., verde, canaliculado, glabro. Inflorescência ca. 5,5-7 cm compr., multiflora, axilar; ráquis achatada, glabra. Brácteas, bractéolas e botão floral não vistos. Hipanto glabro externamente, ápice ca. $0,3 \mathrm{~mm}$ prolongado sobre o ovário; lobos do cálice ca. $0,7 \mathrm{~mm}$ compr., triangulares, ápice agudo, glabros, pontuações impressas; pétalas não vistas; estames de filetes glabros, anteras oblongas; pistilo não visto. Fruto imaturo verde, globoso, glabro, verrucoso-glandular,; resquícios do cálice reflexos; semente 2 por fruto, testa crustácea.

Material examinado: 8.I.2006, fr., M.F. Santos et al. 54 (BHCB, SPF, VIC).

Myrcia laruotteana é caracterizada por apresentar lâmina foliar com base retusa, margem ondulada quando seca e lobos do cálice reflexos no fruto. Em Ouro Branco, a espécie foi encontrada na borda de mata ripária, no fim do período de frutificação. No Brasil, distribui-se pelo Distrito Federal e pelos estados do Espírito Santo, Maranhão, Mato Grosso, Mato Grosso do Sul, Minas Gerais, Paraná, Rio Grande do Sul, Santa Catarina, São Paulo e Tocantins (Sobral et al. 2012).

8.5. Myrcia obovata (O.Berg) Nied., Nat. Pflanzenfam. 3(7): 761. 1893.

Arbusto a arvoreta ca. $2 \mathrm{~m}$ alt., ramos glabros. Lâmina foliar 3,7-6,6 × 2,2-4 cm, coriácea, elíptica a largamente elíptica ou obovada, ápice arredondado a emarginado, base obtusa a atenuada, margem plana, glabra, pontuações salientes; face adaxial com nervura central impressa a saliente, nervuras laterais inconspícuas; face abaxial com nervura central saliente, nervuras laterais tênues; pecíolo 4-8 mm compr., rubro, fortemente canaliculado a plano, glabro. Inflorescência ca. 5-6,5 cm compr., multiflora, subterminal; ráquis achatada, glabra. Brácteas e bractéolas não vistas. Botão floral ca. 2,5 mm compr., obcônico. Hipanto piloso a glabro externamente, verrucoso-glandular, ápice ca. $\mathrm{mm} 1,3$ prolongado sobre o ovário; lobos do cálice ca. $1 \mathrm{~mm}$ compr., orbiculares ou depresso-ovados, ápice arredondado, externamente glabros, internamente pilosos a glabros, pontuações impressas; pétalas ca. 3 mm compr., orbiculares, glabras, pontuações salientes; estames de filetes glabros, anteras oblongas ou quadradas; ovário 3-locular, estilete cilíndrico, glabro. Fruto imaturo verde, quando maduro rubro a vináceo, globoso, glabro, verrucoso-glandular; cálice patente; semente 1-2 por fruto.

Material selecionado: 9.I.2006, fr., M.F. Santos et al. 62 (BHCB, SPF, VIC); 1.X.1988, fl., (BHCB 14468).

Myrcia obovata é caracterizada pelas folhas coriáceas, elípticas a largamente elípticas ou obovadas com ápice arredondado a emarginado e glabras. A espécie é muito semelhante à Myrcia guianensis (Aubl.) DC., espécie de ampla distribuição ainda não registrada na Serra do Ouro Branco, da qual se diferencia pelas folhas obovais, coriáceas e glabras, com ápice arredondado ou emarginado e inflorescências glabras (Kawasaki 1989). Na Serra do Ouro Branco, foi coletada em floração em outubro e frutificação em janeiro. Na região, habita os capões de mata. Distribui-se por Bahia e Minas Gerais (Sobral et al. 2012).

8.6. Myrcia retorta Cambess., Fl. Bras. Merid. 2: 322. 1832.

Fig. 3c

Arvoreta ca. 2 m alt., caule tortuoso, descamação acentuada, ramos imaturos pilosos, quando maduros glabros. Lâmina foliar 2,1-5,2 × 1,1-2,1 cm, subcoriácea, elíptica ou ovada, ápice agudo, obtuso ou arredondado, base obtusa, arredondada ou truncada, margem plana ou revoluta; face adaxial glabra, pontuações impressas, nervura central sulcada, nervuras laterais inconspícuas; face abaxial tomentosa, desigualmente glabrescente, pontuações impressas ou inconspícuas, nervura central saliente, nervuras laterais levemente salientes a inconspícuas; pecíolo 2-6 mm compr., canaliculado, piloso a glabro. Inflorescência ca. 3,6-4,2 cm compr., multiflora, subterminal; ráquis achatada, pilosa. Brácteas, bractéolas e botão floral não vistos. Hipanto externamente pubérulo, ápice não-prolongado sobre o ovário; lobos do cálice ca. $1 \mathrm{~mm}$ compr., ovados a arredondados, côncavos, ápice arredondado, externamente glabros (raramente com tricomas esparsos), verrucoso-glandulares ou apenas pontuações salientes, internamente pilosos; pétalas e estames não vistos; ovário 4-locular, estilete cilíndrico, glabro. Fruto maduro rubro a negro, globoso, glabrescente a glabro, verrucoso-glandular; cálice patente a reflexo; semente 1 por fruto, testa crustácea. 
Material selecionado: 12.I.2003, fr., A.O. Araújo et al. 351 (ESA, SPF); 9.I.2006, fr., M.F. Santos et al. 63 (SPF, VIC); 10.I.2006, fr., M.F. Santos et al. 94 (SPF).

Myrcia retorta é caracterizada pelo caule tortuoso, pela lâmina foliar com face abaxial tomentosa desigualmente glabrescente (em tufos) e pelo ovário 4-locular. Na Serra do Ouro Branco, foi encontrada em frutificação no mês de janeiro. Espécie comum na região, habita desde borda de capão de mata até campos graminosos, incluindo também afloramentos rochosos. Ocorre nos estados de Minas Gerais, Paraná, Rio Grande do Sul, Santa Catarina e São Paulo (Sobral et al. 2012).

8.7. Myrcia splendens (Sw.) DC., Prodr. 3: 244. 1828.

Fig. 3d-e

Arvoreta 2-3m alt., caule reto, ramos imaturos seríceos, ramos maduros glabrescentes a glabros. Lâmina foliar 1,9-13,5 × 0,6-4,3 cm, cartácea a subcoriácea, estreitamente elíptica a elíptica ou lanceolada, ápice acuminado a rostrado, base aguda, margem plana a revoluta, mais fortemente na base; face adaxial glabra ou pilosa apenas na nervura central, com tricomas esparsos, pontuações inconspícuas ou raras, nervura central impressa a sulcada, nervuras laterais inconspícuas ou impressas a levemente salientes, reticuladas ou não; face abaxial serícea a seríceo-pubescente ou tomentosa a pubérula, pontuações inconspícuas, nervura central saliente, nervuras laterais inconspícuas a salientes; pecíolo 1-10 mm compr., canaliculado, piloso a glabrescente. Inflorescência ca. 0,7-15,5 cm compr., pauciflora a multiflora, axilar ou subterminal; ráquis achatada, pubérula ou tomentosa. Brácteas não vistas. Bractéolas 1,1-2,3 mm compr., estreitamente triangulares a lineares, planas, ápice agudo a acuminado, base truncada, pilosas. Botão floral ca. 1,9 mm compr., globoso a obovado. Hipanto híspido ou seríceo externamente, ápice nãoprolongado sobre o ovário; lobos do cálice ca. 1 $\mathrm{mm}$ compr., ovado-triangulares a suborbiculares, ápice obtuso a arredondado, externamente pilosos a seríceo-pubescentes ou híspidos, internamente pubérulos a glabros, pontuações impressas a salientes; pétalas 2,1-5 mm compr., orbiculares, côncavas, externamente pilosas a seríceas na porção mediana, internamente pilosas a glabras, pontuações impressas; estames de filetes glabros, anteras oblongas; ovário 2-locular, estilete cilíndrico, com tricomas esparsos. Fruto verde quando imaturo, rubro a vináceo quando maduro, elipsoide, seríceoglabrescente, verrucoso-glandular; cálice patente; semente 1-4 por fruto, testa crustácea.
Material selecionado: 1.X.1988, fl., G.F. Amorim (BHCB 13914); 26.IX.2004, fl., C.C. Paula 834 (SPF, VIC); 8.I.2006, fr., M.F. Santos et al. 56 (BHCB, SPF, VIC); 9.I.2006, fr., M.F. Santos et al. 67 (K, SPF, VIC).

Myrcia splendens apresenta enorme variabilidade morfológica, o que a torna difícil de caracterizar. Dentre as espécies de Myrcia coletadas na Serra do Ouro Branco, M. eriocalyx e M. eriopus são similares à $M$. splendens, que se diferencia pela pilosidade predominantemente serícea e pela inflorescência multiflora. Foi coletada em floração em setembro e outubro e em frutificação em janeiro. Comumente encontrada nos capões de mata da área, principalmente nas áreas de borda. Distribui-se por toda América Tropical (Govaerts et al. 2006) e no Brasil ocorre em todos estados, exceto Maranhão e Piauí (Sobral et al. 2012).

\subsection{Myrcia subverticillaris (O. Berg) Kiaersk.,} Enum. Myrt. Bras.: 88. $1893 . \quad$ Fig. 3f-g

Arbusto 1,5-2,5 m alt., ramos imaturos vilosos, ramos maduros glabros. Filotaxia suboposta, alterna ou verticilada (raramente oposta); lâmina foliar 2,5-6 × 0,9-1,4 cm, discolor, coriácea, elíptica a obovada, ápice arredondado ou emarginado, base aguda, margem plana, pilosidade avermelhada; face adaxial glabrescente a glabra, pontuações impressas ou inconspícuas, nervura central impressa a saliente, nervuras laterais inconspícuas; face abaxial vilosa a pubérula, pontuações raras e salientes, nervura central saliente, nervuras laterais inconspícuas a levemente salientes; pecíolo 3-9 mm compr., canaliculado, viloso a glabrescente. Inflorescência $3,7-4,7 \mathrm{~cm}$ compr., multiflora, axilar, às vezes subterminal; ráquis achatada, vilosa. Brácteas não vistas. Bractéolas ca. 1,9 mm compr., lanceoladas, ápice agudo, base truncada, tomentosas. Botão floral ca. 1,5 mm compr., globoso. Hipanto tomentoso a glabro externamente, verrucoso-glandular, ápice ca. 1,5 $\mathrm{mm}$ prolongado sobre o ovário; lobos do cálice ca. 1,6 mm compr., vináceos, largamente ovados a depresso-ovados, ápice obtuso a arredondado, externamente glabrescente, verrucoso-glandulares, internamente tomentosos; pétalas ca. 1,6 mm compr., alvas, glabras, pontuações impressas; estames de filetes glabros, anteras oblongas a transversalmente oblongas; ovário 2-3-locular, estilete cilíndrico, glabro. Fruto maduro rubro, globoso-achatado, glabro, verrucoso-glandular; cálice persistente ou apenas resquícios, patente; sementes 1-2 por fruto, testa membranácea.

Material selecionado: 29.VII.1988, fl., M.M.N. Braga et al. (BHCB 13691); 19.IX.1998, fl., P.O. Morais 20 \& A. Salino (BHCB); 28.II.2003, fl. e fr., C.C. Paula et al. 695 
(SPF, VIC); 9.I.2006, fr., M.F. Santos et al. 65 (BHCB, SPF, VIC); 10.I.2006, fr., M.F. Santos et al. 92 (SPF, VIC).

Myrcia subverticillaris apresenta filotaxia pouco comum em Myrcia (suboposta, alterna ou verticilada, raramente oposta), o que, junto com outras características conspícuas, como o indumento viloso na face abaxial e o ápice da lâmina foliar emarginado, a torna facilmente reconhecível. $\mathrm{Na}$ região, foi coletada florescendo em janeiro, fevereiro, julho e setembro, com frutos imaturos em janeiro e fevereiro. Os indivíduos, em geral, apresentam grande número de frutos. Na Serra do Ouro Branco é frequente, sendo encontrada desde os afloramentos rochosos até as bordas de mata. Ocorre apenas em Minas Gerais (Sobral et al. 2012).

8.9. Myrcia tomentosa (Aubl.) DC., Prod. 3: 245. 1828.

Árvore ca. $4 \mathrm{~m}$ alt., caule descamante por grandes tiras, ramos imaturos tomentosos, ramos maduros glabros. Filotaxia oposta; lâmina foliar $5,7-12 \times(1,8) 3-6,4 \mathrm{~cm}$, subcoriácea, obovada ou elíptica (raramente ovada), ápice agudo a obtuso, base aguda a obtusa ou arredondada, margem plana ou revoluta apenas na base, pilosidade amarelada, nervação lateral encurvada; face adaxial glabra (raramente com tricomas esparsos), pontuações impressas, nervura central impressa a sulcada, nervuras laterais impressas; face abaxial tomentosa, pontuações impressas a salientes, nervação saliente, nervuras laterais salientes; pecíolo 8-14 mm compr., canaliculado, tomentoso a glabro. Inflorescência ca. 5-8,5 cm compr., multiflora, axilar; ráquis achatada, tomentosa; apenas flores sésseis. Brácteas, bractéolas e botão floral não vistos. Hipanto tomentoso externamente, ápice ca. $0,4 \mathrm{~mm}$ prolongado sobre o ovário; lobos do cálice $0,7-1 \mathrm{~mm}$ compr., triangulares ápice agudo, externamente tomentosos, internamente glabros; pétalas ca. $2 \mathrm{~mm}$ compr., orbiculares, côncavas, glabras; estames de filetes glabros, anteras oblongas; ovário 2-locular, estilete cilíndrico, glabro. Fruto globoso, tomentoso a glabrescente, verrucosoglandular; cálice persistente e reflexo ou decíduo; semente 1-2 por fruto.

Material selecionado: 9.I.2006, fr., M.F. Santos et al. 70 (BHCB, F, K, SPF, VIC).

Myrcia tomentosa apresenta panícula com todas as flores sésseis, fato incomum no gênero, o que torna sua identificação relativamente fácil. No campo, é facilmente identificável pelo caule semelhante ao de Psidium guajava L. (goiabeira). $\mathrm{Na}$ Serra do Ouro Branco, foi coletada em frutificação no mês de janeiro, habitando as bordas de capão de mata. Sua distribuição engloba a ilha de Trinidad (Trinidad \& Tobago) e a América do Sul tropical (Govaerts et al. 2006).

8.10. Myrcia venulosa DC., Prodr. 3: 250. 1828. Árvore 3-5 m alt., caule sem descamação acentuada, ramos imaturos vilosos, ramos maduros glabros. Filotaxia oposta; lâmina foliar 2,1-7,1 × 0,9-2,9 cm, subcoriácea, elíptica, ápice agudo a obtuso, base aguda a obtusa, margem revoluta, mais fortemente na base, pilosidade avermelhada, nervação lateral densamente reticulada; face adaxial glabra ou tricomas esparsos apenas na nervura central, pontuações impressas, nervura central sulcada (raramente impressa), nervuras laterais impressas a salientes; face abaxial vilosa a glabrescente, pontuações inconspícuas, nervação saliente; pecíolo 2-7 mm compr., canaliculado, viloso a glabrescente. Inflorescência 2,1-6,5 cm compr., multiflora, axilar, subterminal ou terminal; ráquis achatada, vilosa; flores sésseis e pediceladas. Brácteas, bractéolas e botão floral não vistos. Hipanto viloso externamente, ápice ca. $0,8 \mathrm{~mm}$ prolongado sobre o ovário; lobos do cálice ca. $1 \mathrm{~mm}$ compr., esverdeados, largamente ovados a ovado-triangulares, ápice obtuso, externamente vilosos a pubérulos, verrucosoglandulares, internamente tomentosos a pubérulos; pétalas ca. $2 \mathrm{~mm}$ compr., creme, orbiculares, glabras, pontuações salientes; estames de filetes glabros, anteras oblongas a transversalmente oblongas; ovário 3-locular, estilete cilíndrico, com tricomas. Fruto globoso-achatado, glabrescente, verrucoso-glandular; cálice patente; sementes não vistas.

Material selecionado: 22.XII.2002, fl., C.C. Paula et al. 562 (VIC, SPF); 9.I.2006, fr., M.F. Santos et al. 71 (BHCB, F, K, RB, SPF, VIC).

Myrcia venulosa é caracterizada pela nervação densamente reticulada em ambas as faces da lâmina foliar e pela pilosidade densa, cuja coloração varia de ocrácea a avermelhada (Kawasaki 1989). Foi coletada na Serra do Ouro Branco em floração no mês de dezembro e em início de frutificação em janeiro. Na região, habita as bordas de capão de mata. Ocorre nos estados da Bahia, Espírito Santo, Goiás, Minas Gerais, Paraná, Rio de Janeiro, Santa Catarina e São Paulo (Sobral et al. 2012).

\section{Psidium L.}

9.1. Psidium firmum O. Berg, F1. bras. 14(1): 390. 1857.

Subarbusto ca. $20 \mathrm{~cm}$ alt., ramificação monopodial, ramos glabros. Lâmina foliar 4,8-7,4 × 
2,1-4,1 cm, coriácea, elíptica a ovada, ápice agudo a obtuso, base arredondada (raramente obtusa), margem revoluta, glabra, numerosas pontuações presentes; face adaxial com nervura central impressa a saliente, nervuras laterais salientes; face abaxial com nervura central saliente, nervuras laterais levemente salientes; pecíolo $4 \mathrm{~mm}$ compr., semi-cilíndrico, glabro. Inflorescência terminal, 1-flora. Pedicelo ca. $5 \mathrm{~mm}$ compr., glabro. Brácteas não vistas. Bractéolas ca. 2,4 $\mathrm{mm}$ compr., persistentes, triangulares, côncavas, ápice agudo, glabras, externamente verrucoso-glandulares. Botão floral não visto. Flor 5-mera; hipanto glabro externamente, ápice não-prolongado sobre o ovário; cálice aberto no botão floral, lobos ca. $3 \mathrm{~mm}$ compr., ovado-triangulares, ápice obtuso, ciliados, verrucosoglandulares; pétalas ca. $4 \mathrm{~mm}$ compr., orbiculares, ciliadas; estames de filetes glabros, anteras oblongas; ovário 4-locular, estilete cilíndrico, glabro, estigma capitado. Fruto discoide, glabro, verrucoso-glandular; cálice e bractéolas persistentes; semente várias por fruto, reniforme, testa óssea; embrião mirtoide.

Material examinado: 10.I.2006, fr., M.F. Santos et al. 91 (SPF).

Psidium firmum diferencia-se das outras espécies de Myrtaceae da Serra do Ouro Branco por apresentar folhas fortemente coriáceas, inflorescência terminal 1-flora, cálice aberto no botão floral e semente com testa óssea. Foi coletado um espécime com fruto em janeiro, em vegetação campestre próxima à transição para capão de mata. Ocorre nos estados da Bahia, Goiás, Minas Gerais e São Paulo, além do Distrito Federal (Sobral et al. 2012).

\section{Siphoneugena O. Berg}

10.1. Siphoneugena crassifolia (DC.) Proença \& Sobral, Phytotaxa 8: 57. $2010 . \quad$ Fig. 3h

Arvoreta ca. 1,5 m alt., caule fissurado, ramificação monopodial, ramos com pilosidade alva. Lâmina foliar 5,2-6,8 × 1,5-2 cm, subcoriácea, obovada ou elíptica, ápice agudo a acuminado, base aguda, margem revoluta; face adaxial com tricomas esparsos, pontuações inconspícuas, nervura central saliente, nervuras laterais inconspícuas; face abaxial pubérula, pontuações numerosas, nervura central saliente, nervuras laterais inconspícuas; pecíolo 3-6 $\mathrm{mm}$ compr., canaliculado, glabro a piloso. Inflorescência em racemos axilares, em nós desfolhados, eixo principal muitas vezes encurtado. Brácteas ca. 1 mm compr., persistentes, ovadas, ápice agudo a obtuso, ciliadas, pontuações inconspícuas. Bractéolas idem brácteas, mas geralmente menores. Botão floral ca. $6 \mathrm{~mm}$ compr., clavado, aberto apenas no ápice do cálice. Flor 4-mera; hipanto tubuloso, ápice ca. 2-3 $\mathrm{mm}$ prolongado acima do ovário, circunciso na altura do ovário após a antese; cálice aberto apenas no ápice no botão floral, lobos irregulares na antese, decíduos, externamente glabros, internamente tomentosos; pétalas ca. 1,5 mm compr., orbiculares, pubérulas; estames de filetes glabros, anteras oblongas; ovário 2-locular, estilete cilíndrico, glabro, estigma punctiforme. Fruto não visto.

Material examinado: 8.I.2006, M.F. Santos et al. 59 (SPF).

Material adicional examinado: BRASIL. MINAS GERAIS: Santana do Riacho, km 123 da rodovia Belo Horizonte - Conceição do Mato Dentro, 23.VIII.1980, fl., A. Furlan et al. CFSC 6456 (K, SPF, RB).

Siphoneugena crassifolia é caracterizada por apresentar inflorescência em racemo, botão floral clavado, hipanto tubuloso muito prolongado e circunciso após a antese. Na Serra do Ouro Branco, foi coletado apenas um indivíduo infértil, habitando a borda de uma mata ripária. Ocorre em regiões montanhosas do Espírito Santo, Minas Gerais, São Paulo e Paraná (Proença 1990; Sobral et al. 2012).

\section{Agradecimentos}

Agradecemos ao CNPq as bolsas concedidas aos autores; à Fapesp (processo 2010/09473-0) a bolsa concedida ao primeiro autor; ao Prof. Dr. Marcos Sobral a ajuda na identificação das espécies; ao Prof. Dr. Claúdio Coelho de Paula o convite para a realização deste trabalho; a Leonardo Borges o auxílio nas pranchas; à Gerdau-Açominas o apoio logístico e financeiro; aos funcionários e colaboradores do Laboratório de Sistemática Vegetal da USP, Abel, Fabiana e Elisa, todo auxílio.

\section{Referências}

Almeida-Abreu, P.A. 1995. O supergrupo Espinhaço da Serra do Espinhaço Meridional (Minas Gerais): o rifte, a bacia e o orógeno. Geonomos 3: 1-18.

Almeida-Abreu, P.A. \& Renger, F.E. 2002. Serra do Espinhaço Meridional: um orógeno de colisão do mesoproterozóico. Revista Brasileira de Geociências 32: 1-14.

Angiosperm Phylogeny Group (APG III). 2009. An update of the Angiosperm Phylogeny Group classification for the orders and families of flowering plants: APG III. Botanical Journal of the Linnean Society 161: 105-121.

Berg, O. 1855-1856. Revisio Myrtacearum Americae. Linnaea 27: 1-472.

Berg, O. 1857-59. Myrtaceae. In: Martius, C.F.P. von(ed.). Flora brasiliensis. Munchen. Vol. 14. Pp. 1-655. 
Biodiversitas. 2007. Revisão das listas das espécies da flora e da fauna ameaçadas de extinção do estado de Minas Gerais. Disponível em $<$ http://www.biodiversitas.org. br/listas-mg/> Acesso em 16 Ago 2012.

Giulietti, A.M.; Menezes, N.L.; Pirani, J.R.; Meguro, M. \& Wanderley, M.G.L. 1987. Flora da Serra do Cipó - Minas Gerais: caracterização e lista de espécies. Boletim de Botânica da Universidade de São Paulo 9: 1-151.

Govaerts, R.; Sobral, M.; Ashton, P.; Barrie, F.; Holst, B.; Landrum, L.R.; Lucas, E.; Matsumoto, K.; Mazine, F.; Proença, C.; Soares-Silva, L.; Wilson, P. \& NicLughadha, E. 2006. World Checklist of Myrtaceae. Royal Botanic Gardens, Kew. 454p.

Johnson, L.A.S. \& Briggs, B.G. 1984. Myrtales and Myrtaceae-a phylogenetic analysis. Annals of the Missouri Botanical Garden 71: 700-756.

Kawasaki, M.L. 1989. Flora da Serra do Cipó, MG, Brasil: Myrtaceae. Boletim de Botânica da Universidade de São Paulo 11: 121-170.

Kawasaki, M.L. 2004. Flora de Grão-Mogol, Minas Gerais: Myrtaceae. Boletim de Botânica da Universidade de São Paulo 22: 323-337.

Landrum, L.R. 1981. A monograph of the genus Myrceugenia (Myrtaceae). Flora Neotropica 29: 1-137.

Landrum, L.R. 1986. Campomanesia, Pimenta, Blepharocalyx, Legrandia, Acca, Myrrhinium, and Luma (Myrtaceae). Flora Neotropica 45: 1-179.

Landrum, L.R. 1990. Accara: A new genus of Myrtaceae, Myrtinae from Brazil. Systematic Botany 15: 221-225.

Landrum, L.R. \& Kawasaki, M.L. 1997. The genera of Myrtaceae in Brazil: an illustrated synoptic treatment and identification keys. Brittonia 49: 508-536.

Lucas, E.J.; Belsham, S.R.; Nic Lughadha, E.M.; Orlovich, D.A.; Sakuragui, C.M.; Chase, M.W. \& Wilson, P.G. 2005. Phylogenetic patterns in the fleshy-fruited Myrtaceae -preliminary molecular evidence. Plant Systematic Evolution 251: 35-51.

Lucas, E.J.; Harris, S.A.; Mazine, F.F.; Belsham, S.R.; Nic Lughadha, E.M.; Telford, A.; Gasson, P.E. \& Chase, M.W. 2007. Suprageneric phylogenetics of Myrteae, the generically richest tribe in Myrtaceae (Myrtales). Taxon 56: 1105-1128.

Lucas, E.J.; Matsumoto, K.; Harris, S.A.; Nic Lughadha, E.M.; Benardini, B. \& Chase, M.W. 2011. Phylogenetics, morphology, and evolution of the large genus Myrcia s.1. (Myrtaceae). International Journal of Plant Sciences 172: 915-934.

Mazine, F.F. 2006. Estudos taxonômicos em Eugenia L. (Myrtaceae), com ênfase em Eugenia sect. Racemosae O. Berg. Tese de Doutorado. Universidade de São Paulo, São Paulo. 224p.

McVaugh, R. 1968. The genera of American Myrtaceae - an interim report. Taxon 17: 354-418.
Morais, P.O \& Lombardi, J.A. 2006. A família Myrtaceae na Reserva Particular do Patrimônio Natural da Serra do Caraça, Catas Altas, Minas Gerais, Brasil. Lundiana 7: 3-32.

Nic Lughadha, E. 1995. Myrtaceae. In: Stannard, B.L. (ed.). Flora of the Pico das Almas, Bahia, Brazil. Royal Botanic Garden, Kew. Pp. 492-517.

Nic Lughadha, E. \& Snow, N. 2000. Biology and evolution of the Myrtaceae: a symposium. Kew Bulletin 55: 591-592.

Oliveira-Filho, A.T. \& Fontes, M.A.L. 2000. Patterns of floristic differentiation among Atlantic forests in SE Brazil and the influence of climate. Biotropica 32: 793-810.

Pirani, J.R.; Mello-Silva, R. \& Giulietti, A.M. 2003. Flora de Grão-Mogol, Minas Gerais, Brasil. Boletim de Botânica da Universidade de São Paulo 21: 1-24.

Proença, C. 1990. Arevision of Siphoneugena (Myrtaceae). Edinburgh Journal of Botany 47: 239-271.

Proença, C.E.B.; Nic Lughadha, E.M.; Lucas, E.J \& Woodgyer, E.M. 2006. Algrizea (Myrteae, Myrtaceae): Anew genus from the highlands of Brazil. Systematic Botany 31: 320-326.

Radford, A.E.; Dickson, W.C.; Massey, J.R. \& Bell, C.R. 1974. Vascular plant systematics. Harper \& Row Publ., New York. 891p.

Schmid, R. 1972. A resolution of the Eugenia-Syzygium controversy (Myrtaceae). American Journal of Botany 59: 423-436.

Sobral, M.; Proença, C.; Souza, M.; Mazine, F. \& Lucas, E. 2012. Myrtaceae. In: Lista de Espécies da Flora do Brasil. Jardim Botânico do Rio de Janeiro, Rio de Janeiro. Disponível em $<$ http://floradobrasil.jbrj.gov. br/2012/FB000171>. Acesso 16 Ago 2012.

Thiers, B. [em contínua atualização]. Index herbariorum: a global directory of public herbaria and associated staff. The New York Botanical Garden, New York. Disponível em $<$ http://sweetgum.nybg.org/ih/>. Acesso em 16 Ago 2012.

Wilson, P.G.; O’Brien, M.M.; Gadek P.A. \& Quinn, C.J. 2001. Myrtaceae revisited: a reassessment of infrafamilial groups. American Journal of Botany 88: 2013-2025.

Wilson, P.G.; O’Brien, M.M.; Heslewood, M.M. \& Quinn, C.J. 2005. Relationships within Myrtaceae sensu lato based on a matK phylogeny. Plant Systematics and Evolution 251: 3-19.

Zappi, D.C.; Lucas, E.; Stannard, B.L.; Lughadha, E.M.; Pirani, J.R.; Queiroz, L.P.; Atkins, S.; Hind, D.J.N.; Giulietti, A.M.; Harley, R.M. \& Carvalho, A.M. 2003. Lista das plantas vasculares de Catolés, Chapada Diamantina, Bahia, Brasil. Boletim de Botânica da Universidade de São Paulo 21: 345-398. 
